\section{Twinning and Branch Campuses: The Professorial Obstacle}

\section{Philip G. Altbach}

Philip G. Altbach is Monan professor of higher education and director of the Center for International Higher Education at Boston College.

$\mathrm{B}^{\mathrm{r}}$ ranch campuses, twinning arrangements, and other manifestations of cross-border higher education are booming. Universities in Europe, Australasia, and North America see a huge market by offering their degrees in other countries. At the same time, Singapore and several of the states in the Arabian Gulf have identified themselves as educational centers and are attracting international higher education providers. In the Gulf, there is even competition for attracting overseas universities. China has opened its doors to foreign institutions, and India is moving in this direction.

While there are no accurate numbers, more than 500 branch campuses exist worldwide-plus thousands of "twinned" programs. In addition, the phenomenon of the "American University of ..." manifests another trend in crossborder higher education. There are a dozen or more such universities, some of which have a direct link with a US university while many simply use the name "American" and offer a US-style curriculum in English in a non-US setting. If the General Agreement on Trade in Services (GATS) becomes part of the structure of international academic arrangements, the numbers of all kinds of cross-border institutions will increase even faster.

One significant problem exists with these arrangements. Who is teaching the students at these branch campuses? What does a degree from a university signify if the teaching staff are not from the university offering the degree? To use the McDonald's analogy-is the meal (degree) a true McDonald's hamburger if only the recipe (the curriculum) comes from McDonalds. The rest of the process - the ingredients (facilities) and the cooks (professors) - are local, rather than from the sponsoring institution. Should a university in the United Kingdom (or another country) claim to offer a degree overseas if only the curriculum is from the sponsoring school, perhaps along with an element of quality control?

With little data indicating the proportion of faculty members from the home universities teaching at branch or twinning campuses, anecdotal evidence shows that the numbers are small and most of the teaching is carried out by professors who are not faculty from the sponsoring institution. Even when they do come from the home university, faculty teaching at branch or twinned campuses are generally not the "star" research-active professors.

It is not known if some of the recent high-prestige universities that have entered the branch campus business-the University of Chicago, the Cornell University Medical School, the University of Nottingham, and others-have a different profile than the many more average institutions thus far engaged.

\section{THE BaCKGROUND OF TeAchers}

Many faculty members are hired locally_some "moonlighting" from a local university. Other "local hires" are full-time staff, obtained from the local academic market or attracted away from local or regional institutions. Some faculty are natives of the country of the sponsoring university but not faculty members at that institution. For example, an American university in Singapore might hire an American working in Japan or Taiwan. PhD holders who are teaching part time or on short-term assignments in the home country may also be attracted to work overseas. The sponsoring university generally tries to ensure that these faculty have a doctoral degree from a respectable institution-insofar as possible from the country where the sponsoring university is located.

\section{Attracting Top-Quality Faculty}

At branch campuses this task may not be easy, particularly on an assignment of a year or more. Except for a few specialists in the culture where the branch is located or professors committed to learning about foreign cultures, an overseas assignment as a full-time member of the academic staff at a university in Europe, North America, or Australia may not lure prominent faculty. In addition to the challenges of uprooting families, finding schools for children, and the like, an overseas assignment disrupts the rhythm of academic life. For younger professors seeking to obtain tenure and promotion, an overseas assignment is particularly dangerous. It will inevitably disrupt
Who is teaching the students at these branch campuses? What does a degree from a university signify if the teaching staff are not from the univer- sity offering the degree?

a research agenda and in the sciences may make research impossible given the lack of equivalent laboratory equipment and staff. Since branch campuses are always oriented toward teaching rather than research, teaching loads are often higher than at the home university. Libraries and other facilities are never the same either.

Many branch campuses offer faculty members from the home university additional perquisites - such as housing, transportation for families, payment of school fees, and others. 
In some cases, salary supplements are provided, and there is usually a tax advantage. But even these benefits may not produce a sufficient attraction.

As a result of these factors, the professors teaching at branch campuses are seldom full-time research-active faculty from the home university. If from the home institution, they are often senior staff close to retirement or those with fewer commitments at home. Most are not from the home university. Relevant academic departments at home often must approve the academic qualifications of these professors and offer them some kind of temporary appointment to legitimize their appointments.

\section{CONCLUSION}

Does an academic degree mean that a student has studied at the university offering the degree? Does it mean that he or she has been taught by the faculty of that institution? Does it mean that the curriculum and language of instruction of the home university have been used? Is it enough that the home institution has approved the qualifications of the teaching staff and that the general conditions of teaching are considered to be satisfactory? Should teaching be provided by faculty members who are actually on the home institution's staff, or is it acceptable that an itinerant but qualified collection of teachers do the work? Is it acceptable that the prestigious universities whose fame in their home countries is based on excellence in research as well as teaching provide an academic environment in the branch campus almost exclusively devoid of research? Cross-border academic cooperation and transnational higher education are characteristics of the 2Ist century, but it is necessary to carefully examine the realities in order to assess quality and effectiveness.

\section{Problems within Singapore's Global Schoolhouse \\ Cate Gribble and Grant McBurnie}

Cate Gribble is a researcher and Grant McBurnie is a senior associate in the School of Global Studies, Social Science and Planning at the Royal Melbourne Institute of Technology. Address: GPO Box 2476V, Melbourne 3001, Australia.E-mail: cate.gribble@rmit.edu.au; grant.mcburnie@rmit edu.au.

ingapore's Global Schoolhouse strategy, which aims to Sattract I50,000 international students to the city-state by the year 2015, has been dealt a blow by the recent announcement that Australia's University of New South Wales would close its Singapore campus after operating only one semester. In contractual arrangements with Singapore's Economic Development Board, by 2020 the campus was required to have international students comprise up to 70 percent of its projected I5,000 enrollments. The university cited low enrollments (resulting in a multimillion dollar shortfall) and the expectation of further financial losses as reasons for closure. The vice chancellor of the University of South Wales noted that the university had invested AU\$I7.5 (US\$I4.3) million in the project, and millions more dollars would be spent on redundancy packages and other exit costs. The Singapore government also contributed resources to the operation, but the total has not been made public. This closure follows less than a year after the July 2006 announcement that the biomedical research facility of the US Johns Hopkins University in Singapore (established I998) would close within a year. The Singapore government's Agency for Science, Technology and Research, discontinued its substantial funding, claiming that various key performance indicators had not been met-including failure to meet targets for PhD enrollments and targets for attracting leading medical researchers to migrate to Singapore.

\section{Hub Ambitions}

It is now a decade since Singapore set its target of attracting Io world-class foreign institutions to establish on its soil within Io years. The government has exceeded its own forecast: there are now I5 such institutions-from China, the United States, France, India, Germany, and the Netherlands. The elite foreign providers, for the most part offering niche programs, are expected to attract chiefly international students. (Conversely, public institutions must cap international student enrollments at 20 percent.) In addition, foreign programs offered in partnership with I40 local private providers are helping to meet demand from local and foreign students who have not been able to attend Singapore's prestigious public universities or top-notch foreign institutions. According to official statistics, in 2004 transnational education enrollments comprised 36 percent (or more than 80,000) of all higher education students in Singapore.

In 2006 some 80,000 international students were studying in Singapore, an II percent increase from the previous year. While Singapore is clearly proving to be a popular destination for students from Asia, small numbers of students from Europe, the United States, and Australia are also choosing to study in Singapore. Many international students consider Singapore to be a comfortable introduction to Asia, providing both the chance to get a Western education at a leading institution and become familiar with Chinese language and business practices.

\section{REALISTIC TARGETS?}

The Global Schoolhouse strategy is driven by considerations of economic development and recruitment of skilled immigration. The latter is a considered country response to a low 